\title{
KANDUNGAN PIGMEN DAN POTENSI ANTIOKSIDAN BEBERAPA JENIS MAKROALGA DARI PANTAI GUNUNGKIDUL, YOGYAKARTA
}

\section{Pigments Content and Antioxidant Potential of Several Species of Macroalgae from the Coast of Gunungkidul, Yogyakarta}

\author{
Wiwin Kusuma Perdana Sari ${ }^{1 *}$ dan Suharyanto ${ }^{2}$ \\ ${ }^{1}$ Loka Riset Budidaya Rumput Laut, Badan Riset dan Sumber Daya Manusia Kelautan dan Perikanan, \\ JI. Pelabuhan Etalase Perikanan, Boalemo, Gorontalo, 96265, Indonesia \\ ${ }^{2}$ Fakultas Biologi, Universitas Gadjah Mada, Jalan Sekip Utara, Sleman, Yogyakarta, 55281, Indonesia \\ *Korespondensi Penulis: perdhana9@gmail.com
}

Diterima: 11 Mei 2020; Direvisi: 18 Juli 2020; Disetujui: 23 September 2020

\begin{abstract}
ABSTRAK
Makroalga merupakan biota laut yang mengandung berbagai jenis senyawa potensial, termasuk pigmen. Pigmen alami makroalga telah terbukti menunjukkan berbagai aktivitas biologis yang bermanfaat, termasuk sebagai antioksidan. Meskipun informasi mengenai kandungan pigmen maupun potensi antioksidan makroalga dari Pantai Gunungkidul telah banyak diteliti, namun penelitian yang menelaah korelasi antara kandungan pigmen dan aktivitas antioksidan makroalga dari wilayah ini masih terbatas. Berdasarkan hal tersebut, penelitian ini bertujuan untuk mengkaji korelasi kandungan pigmen serta potensi antioksidan beberapa jenis makroalga yang berasal dari Pantai Gunungkidul, Yogyakarta. Enam spesies mewakili kelompok makroalga hijau, merah, dan coklat digunakan pada penelitian ini, yaitu Codium tomentosum, Ulva lactuca, Gelidium corneum, Palisada perforata, Turbinaria ornata, dan Sargassum aquifolium. Hasil pengukuran kandungan pigmen menunjukkan bahwa klorofil a tertinggi terdapat pada jenis $U$. lactuca, klorofil $b$ tertinggi pada C. tomentosum, dan total karotenoid tertinggi pada T. ornata. Dari keenam spesies yang diteliti, T. ornata menunjukkan potensi antioksidan terbaik dalam menangkap radikal bebas DPPH dengan

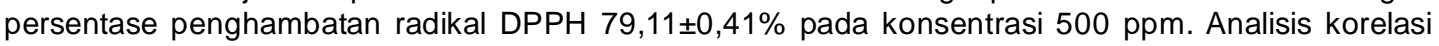
Pearson menunjukkan bahwa potensi antioksidan makroalga berkorelasi positif dengan kandungan total karotenoid $\left(R^{2}=0,806 ; p<0,05\right)$, dan tidak berkorelasi dengan kandungan klorofilnya $\left(R^{2}=0,044\right.$; $p>0,05)$. Hasil studi ini menunjukkan bahwa karotenoid dari berbagai jenis makroalga merupakan kelompok pigmen yang potensial untuk dikembangkan sebagai nutrasetikal antioksidan.
\end{abstract}

KATA KUNCI : makroalga, antioksidan, klorofil, karotenoid, Gunungkidul

\begin{abstract}
Macroalgae are marine biota that contain various types of potential compounds, including pigments. Natural pigments of macroalgae have shown to produce various beneficial biological activities, including antioxidant. Although information regarding the pigment content and antioxidant property of macroalgae from Gunungkidul Coast has been widely studied, research on the correlation between pigment content and its antioxidant activity of macroalgae from this region is still limited. This study aimed to examine the correlation between pigment content of several species of macroalgae from Gunungkidul, Yogyakarta, and its antioxidant potential. Six species representing the green, red, and brown macroalgae were used in this study, i.e. Codium tomentosum, Ulva lactuca, Gelidium corneum, Palisada perforata, Turbinaria ornata, and Sargassum aquifolium. Result of pigment content concentration showed that the highest concentration of chlorophyll a was in U. lactuca, while chlorophyll $b$ was in $\underline{\underline{C}}$. tomentosum, and the highest total carotenoid content was in $\underline{\underline{T}}$ ornata. Of the six species assessed, the brown macroalgae $\underline{T}$. ornata showed the best antioxidant potential in DPPH radical scavenging with a percentage of $\overline{D P P H}$ inhibition $79.11 \pm 0.41 \%$ at $500 \mathrm{ppm}$. The Pearson correlation analysis showed that the antioxidant of the macroalgae positively correlated to the total carotenoid content $\left(R^{2}=0.806 ; p<0.05\right)$, but did not correlate to its chlorophyll content $\left(R^{2}=0.044 ; p>0.05\right)$. This study showed that carotenoids from various species of macroalgae are the group of potential pigments to be developed as antioxidant nutraceuticals.
\end{abstract}

KEYWORDS: macroalgae, antioxidants, chlorophylls, carotenoids, Gunungkidul 


\section{PENDAHULUAN}

Rumput laut dibedakan menjadi tiga kelas yaitu rumput laut merah (Rhodophyceae), rumput laut hijau (Chlorophyceae) dan rumput laut coklat (Phaeophyceae). Pembagian kelas tersebut berdasarkan pada dominansi pigmen yang dikandungnya (Merdekawati \& Susanto, 2009). Kandungan pigmen alami merupakan salah satu potensi alami makroalga laut. Berbagai pigmen alami makroalga laut menunjukkan adanya bioaktivitas dan telah banyak diteliti dalam berbagai studi, salah satunya sebagai antioksidan alami (Pangestuti \& Kim, 2011).

Antioksidan merupakan substansi yang secara efektif dapat mencegah atau memperlambat kerusakan oksidatif yang disebabkan oleh radikal bebas. Makroalga laut merupakan organisme fotosintetik yang banyak menghasilkan radikal bebas ketika terpapar pada intensitas cahaya dan oksigen yang tinggi. Paparan tersebut diatasi dengan adanya mekanisme protektif yang dimiliki makroalga laut untuk melindunginya dari kerusakan struktural. Mekanisme protektif tersebut tampak sebagai potensi antioksidan alami (Munir, Sharif, Naz, \& Manzoor, 2013). Paparan radikal bebas dapat menyebabkan perubahan struktur dan fungsi sel, namun pada alga hal tersebut tidak terjadi. Fakta ini mengindikasikan adanya mekanisme pertahanan antioksidatif pada alga laut (Sedjati, Suryono, Santosa, Supriyantini, \& Ridlo, 2017).

Perairan Pantai Gunungkidul, Yogyakarta merupakan pantai dengan biodiversitas makroalga yang tinggi. Budhiyanti, Raharjo, Marseno, \& Lelana (2012) menyebutkan bahwa Pantai di Kabupaten Gunungkidul merupakan bagian dari Pantai Selatan Daerah Istimewa Yogyakarta, yang didominasi oleh susunan batu karang dan merupakan habitat alami berbagai jenis makroalga. Fakta tersebut mendorong berbagai penelitian dengan objek makroalga alami yang tumbuh di perairan pantai tersebut. Beberapa penelitian mengenai potensi antioksidan makroalga yang berasal dari Pantai Gunungkidul telah dilakukan terhadap beberapa spesies, diantaranya Ulva sp., Turbinaria decurrens, Acantophora muscoides, Sargassum sp., dan Gracilaria verrucosa (Da Costa, Merdekawati, \& Out, 2018; Febrianto, Djunaedi, Suryono, Santosa, \& Sunaryo, 2019; Islami, Ridlo, \& Pramesti, 2014; Kurniasih, Pramesti, \& Ridlo, 2014; Pramesti, Ridlo, Setyati, Zainuddin, \& Akbar, 2017; Sedjati et al., 2017;). Beberapa penelitian tersebut menemukan bahwa makroalga dari Pantai Gunungkidul memiliki pigmen klorofil dan karotenoid (Da Costa et al., 2018; Islami et al., 2014; Kurniasih, et al., 2014; Pramesti et al., 2017). Kadar pigmen yang terdeteksi pada ekstrak makroalga sangat tergantung pada jenis makroalga, jenis pelarut yang digunakan untuk ekstraksi, serta lokasi pengambilan sampelnya (Febrianto, et al., 2019; Islami et al., 2014; Kurniasih, et al., 2014). Beberapa hasil penelitian tersebut menunjukkan hasil yang berbanding lurus antara kadar pigmen dengan potensi antioksidan makroalga, meskipun analisis korelasinya belum dijelaskan secara detail (Febrianto, et al., 2019; Islami, et al., 2014; Kurniasih, et al., 2014). Pigmen alami diketahui berperan dalam mekanisme antioksidatif makroalga (Pangestuti \& Kim, 2011; Rezayian, Niknam, \& Ebahimsadeh, 2019).

Meskipun informasi mengenai kandungan pigmen maupun potensi antioksidan makroalga dari Pantai Gunungkidul telah banyak diteliti, namun penelitian yang menelaah korelasi antara kandungan pigmen dan aktivitas antioksidan makroalga dari wilayah ini masih terbatas. Berdasarkan hal tersebut, penelitian ini bertujuan untuk mengkaji kandungan pigmen serta potensi antioksidan beberapa jenis makroalga yang berasal dari Pantai Gunungkidul. Beberapa jenis makroalga yang digunakan pada penelitian ini mewakili ketiga kelas makroalga, yaitu Rhodophyceae, Chlorophyceae, dan Phaeophyceae; sehingga kandungan pigmen menjadi fokus senyawa potensial antioksidan yang dikaji. Pengukuran potensi antioksidan pada penelitian ini menggunakan metode DPPH karena merupakan metode populer, dapat dilakukan dengan cepat, sederhana, dan relatif murah (Santos-Sanchez, Coronado, Canongo, \& Carlos, 2019).

\section{BAHAN DAN METODE}

\section{Bahan}

Sampel makroalga yang digunakan terdiri atas 6 jenis, yaitu Codium tomentosum, Ulva lactuca, Palisada perforata, Gelidium corneum, Turbinaria ornata, dan Sargassum aquifolium yang diambil dari beberapa pantai di Gunungkidul, Yogyakarta. Makroalga $P$. perforata, $G$. corneum, dan $S$. aquifolium berasal dari Pantai Sepanjang, jenis $C$. tomentosum dan U. lactuca dari Pantai Drini, dan T. ornata dari Pantai Krakal. Identifikasi morfologi dilakukan di Laboratorium Sistematika Tumbuhan, Fakultas Biologi UGM dengan melakukan pencandraan terhadap karakter-karakter diagnostik dari setiap sampel dan membandingkannya dengan karakter diagnostik morfologi dari studi taksonomi yang telah dipublikasi (Ajisaka \& Kilar, 1990; Cassano, et al., 2009; Jan-Malta, Draisma, \& Kamermans, 1999; Kantachumpoo, Uwai, Noiraksar, \& Komatsu, 2015; Lee, 1988; Lee, Hwang, \& Oh, 1992; Lee, Kang, \& Kim, 2019; Martin-Lescanne, et al., 2010; Oliviera-Carvalho, Pereira, \& Pedroche, 2010; Perrone, Felicini, \& Bottalico, 2006; Silva, 1955; Steffensen, 1976; Stewart, 2006; Trowbridge, 2001; Yip, et al., 2018;) dan dari database online (Guiry \& Guiry, 2019). 
Pengambilan sampel dilakukan pada bulan September 2019. Semua jenis makroalga yang dijadikan sampel pada penelitian ini dicuci dan dibersihkan dari berbagai kotoran dan epifit yang melekat, kemudian ditempatkan pada kotak pendingin yang telah dipenuhi dengan es batu untuk menjaga suhu tetap dingin. Sampel kemudian dibawa ke Laboratorium Fakultas Biologi UGM yang berjarak sekitar 2 jam dari lokasi pengambilan sampel. Ekstraksi dilakukan segera setelah sampel sampai di laboratorium, dan dianalisis pada hari berikutnya. Bahan-bahan kimia yang digunakan dalam penelitian meliputi etanol pro-analysis (Merck: 1.00983.2500), metanol pro-analysis (Merck: 1.06009.2500), serbuk DPPH (Sigma Aldrich: D9132-5G), dan asam askorbat (Merck: 1.00468.0100).

\section{Metode}

\section{Ekstraksi makroalga}

Ekstraksi sampel makroalga dilakukan dengan teknik maserasi dengan pelarut etanol pro-analysis. Pelarut etanol dipilih dalam proses ekstraksi ini karena kemampuannya dalam menarik senyawa antioksidan dalam sampel. Sifat etanol yang tidak beracun juga menjadi pertimbangan pada aplikasi lebih lanjut untuk kepentingan manusia. Sekitar $30 \mathrm{~g}$ sampel dipotong kecil-kecil, berukuran panjang $\pm 1 \mathrm{~mm}$, untuk memperluas bidang permukaan dan meningkatkan efektivitas ekstraksi. Sampel kemudian ditempatkan pada beaker glass $1000 \mathrm{~mL}$, kemudian ditambah 300 $\mathrm{mL}$ etanol sebagai pelarutnya, ditutup rapat, dan dibiarkan pada suhu ruang selama 24 jam. Filtrat yang diperoleh diuapkan dengan rotary evaporator (Cole Parmer: Stuart $R E 300$ ) pada suhu $45^{\circ} \mathrm{C}$ hingga pelarut menguap. Ekstrak kemudian dikeluarkan dari labu evaporator dan dipindah pada cawan penguap yang telah diketahui bobotnya, kemudian dipanaskan dengan oven pada suhu rendah $\left(40^{\circ} \mathrm{C}\right)$ untuk menguapkan sisa pelarut. Proses ini dipantau hingga diperoleh berat konstan yang menandai penguapan pelarut telah maksimal, dan terbentuk ekstrak pekat. Cawan berisi ekstrak kemudian ditimbang kembali untuk mengetahui rendemennya.

\section{Pengujian pigmen makroalga}

Pengukuran kandungan pigmen klorofil dan karotenoid dilakukan dengan metode spektrofotometri sesuai metode Lichtenthaler dan Buschmann (2001). Ekstraksi pigmen pada sampel makroalga dilakukan dengan metanol pro-analysis. Pemilihan metanol dalam ekstraksi pigmen didasarkan pada hasil studi yang dilakukan oleh Dere, Gunes, dan Sivaci (1998) yang melaporkan bahwa metanol merupakan pelarut terbaik untuk ekstraksi pigmen makroalga dibandingkan jenis pelarut lainnya. Sebanyak $5 \mathrm{~g}$ talus makroalga dihaluskan menggunakan mortar, kemudian diekstraksi dengan $5 \mathrm{~mL}$ metanol selama 24 jam pada suhu $4^{\circ} \mathrm{C}$ di ruang gelap. Setelah 24 jam, filtrat diambil dan dibaca absorbansinya pada panjang gelombang 470, 653, dan $666 \mathrm{~nm}$. Pengulangan pengukuran dilakukan sebanyak 3 kali. Hasil pengukuran absorbansi dihitung menggunakan rumus Lichtenthaler dan Buschmann (2001), yaitu:

$$
\begin{aligned}
& \text { Klorofil a }\left(C_{a}\right)=15,65 A_{666}-7,340 A_{653} \\
& \text { Klorofil } b\left(C_{b}\right)=27,05 A_{653}-11,21 A_{666} \\
& \text { Total karotenoid }=1000 A_{470}-2,86 C_{a}-129,2 C_{b} / 245
\end{aligned}
$$

\section{Pengujian antioksidan}

Pengujian potensi antioksidan dilakukan berdasarkan metode DPPH dengan preparasi larutan DPPH mengacu pada Nopiyanti dan Harjanti (2016) serta Kosanic, Rankovic, dan Stanojkovic (2019). Sebanyak 0,5 mL larutan DPPH 0,4 mM dalam metanol direaksikan dengan 1,5 mL ekstrak makroalga dengan konsentrasi $500 \mathrm{~mL}$. Konsentrasi yang digunakan pada penelitian ini merupakan modifikasi dari metode aslinya. Penggunaan satu level konsentrasi didasarkan pada paparan Locatelli et al. (2009). Metode ini juga dapat mempersingkat waktu penelitian yang melibatkan beberapa jenis makroalga sekaligus.

Campuran ekstrak dan larutan DPPH dihomogenkan dan direaksikan pada ruang gelap selama 60 menit. Larutan DPPH yang berwarna ungu gelap akan berubah menjadi kuning pucat ketika bereaksi dengan ekstrak yang mengandung antioksidan. Perubahan warna inilah yang diukur dengan spektrofotometer UV-Vis (Genesys-10S) pada panjang gelombang $517 \mathrm{~nm}$. Metanol digunakan sebagai blanko dan asam askorbat 10 ppm sebagai kontrol positif.

Potensi antioksidan ekstrak makroalga diukur berdasarkan kemampuannya dalam menangkap radikal bebas DPPH, berdasarkan persamaan yang dipaparkan oleh Kosanic et al. (2019) sebagai berikut:

Penangkapan radikal DPPH $(\%)=\left[\left(\mathrm{A}_{0}-\mathrm{A}_{1}\right) / \mathrm{A}_{0}\right] \mathrm{x}$ $100 \%$

$\mathrm{A}_{0}=$ Absorbansi kontrol negatif (Larutan DPPH + metanol)

$A_{1}=$ Absorbansi campuran larutan DPPH dengan ekstrak sampel 


\section{Analisis data}

Nilai persentase penghambatan radikal bebas $\mathrm{DPPH}$, kandungan klorofil a, klorofil b, dan total karotenoid ditampilkan sebagai rerata \pm standar deviasi dari tiga pengulangan. Dari data yang diperoleh kemudian dilakukan pra-pengujian normalitas data menggunakan uji normalitas Kolmogorov-Smirnov. Selanjutnya uji sidik ragam satu arah (one-way ANOVA) dan beda nyata terkecil (BNT) dilakukan untuk mengetahui signifikansi perbedaan antar sampel ekstrak $(p<0,05)$ dengan program statistik SPSS versi 25.0. Uji korelasi Pearson dilakukan untuk menegaskan korelasi antara kandungan pigmen dengan potensi antioksidan makroalga.

\section{HASIL DAN PEMBAHASAN}

\section{Rendemen Ekstrak Etanol Makroalga}

Hasil ekstraksi beberapa jenis makroalga dalam penelitian ini menunjukkan adanya perbedaan rendemen dan karakteristik ekstrak yang diperoleh (Tabel 1). Ekstraksi $30 \mathrm{~g}$ sampel makroalga dengan pelarut etanol $(1: 10 \mathrm{w} / \mathrm{v})$ menghasilkan ekstrak terbanyak pada $C$. tomentosum, yaitu $1,58 \mathrm{~g}$ atau sebesar $5,28 \%$ dari berat sampel, sedangkan rendemen terkecil yaitu $G$. corneum dengan berat ekstrak hanya $0,21 \mathrm{~g}$ atau sebesar $0,69 \%$.

Makroalga jenis $C$. tomentosum yang menghasilkan rendemen ekstrak tertinggi di antara jenis lainnya pada penelitian ini juga dilaporkan sebagai penghasil rendemen yang tinggi berdasarkan hasil beberapa studi. Rendemen ekstrak $C$. tomentosum tergolong sangat tinggi hingga mencapai $12-24 \%$ tergantung pada metode ekstraksi dan jenis pelarut yang digunakan (Navya \& Khora, 2017; Seedevi et al., 2013).

Ekstrak yang diperoleh dari suatu proses ekstraksi dapat memiliki rendemen, bentuk, dan warna yang berbeda-beda karena perbedaan kandungan senyawa. Senyawa yang berbeda dapat memiliki tingkat kepolaran yang berbeda. Kepolaran senyawa sangat terkait dengan tingkat kelarutannya terhadap pelarut yang digunakan untuk ekstraksi. Semakin banyak kandungan senyawa dengan tingkat kepolaran yang sama dengan kepolaran pelarut akan menyebabkan semakin banyak ekstrak yang diperoleh (Lutfiyanti, Ma'ruf, \& Dewi, 2012). Bentuk ekstrak yang diperoleh juga bervariasi antar jenis sampel makroalga. Agoes (2009) menyebutkan bahwa bentuk ekstrak yang diperoleh tergantung pada beberapa faktor, yaitu jenis sampel, kondisi alamiah senyawa yang dikandung, kondisi dan waktu penyimpanan sampel, serta teknik pemekatan ekstrak.

\section{Kandungan pigmen makroalga}

Analisis yang dilakukan terhadap kandungan beberapa jenis pigmen menunjukkan hasil yang bervariasi dalam kandungan klorofil a, klorofil b, dan karotenoid total pada beberapa jenis makroalga yang digunakan dalam penelitian ini (Tabel 2). Pengukuran kandungan klorofil terhadap keenam jenis makroalga menunjukkan bahwa U. lactuca mengandung klorofil a dengan kadar tertinggi dibandingkan jenis lainnya. Analisis statistik menunjukkan adanya perbedaan yang signifikan antar sampel makroalga yang diuji. Makroalga $U$. lactuca memang tergolong ke dalam kelompok makroalga hijau yang erat kaitannya dengan dominansi warna hijau pada talusnya.

Kandungan klorofil a makroalga U. lactuca pada penelitian ini menunjukkan nilai yang lebih tinggi dibandingkan pada studi lainnya. Kumar, Ramakritinan, dan Kumaraguru (2010) melaporkan hasil pengukuran klorofil a dari ekstrak etanol dan aseton U. lactuca sebesar 5,92 $\pm 0,02$ dan $6,23 \pm 0,05$. Nilai tersebut lebih rendah dibandingkan hasil yang diperoleh pada penelitian ini, yaitu 7,45 $\pm 0,09$.

Penggunaan jenis pelarut dalam ekstraksi pigmen tampaknya berpengaruh pada perbedaan hasil pengukurannya. Aseton diketahui memiliki

Tabel 1. Hasil ekstraksi 6 jenis makroalga dari Pantai Gunungkidul, Yogyakarta

Table 1. Extraction yield of six macroalgae species taken from Gunungkidul, Yogyakarta

\begin{tabular}{|c|c|c|c|c|}
\hline \multirow[b]{2}{*}{ Jenis/Species } & \multicolumn{2}{|c|}{ Berat/Weight $(\mathrm{g})$} & \multirow{2}{*}{$\begin{array}{c}\text { Rendemen/Yield } \\
(\%)\end{array}$} & \multirow{2}{*}{$\begin{array}{l}\text { Bentuk ekstrak/ } \\
\text { Extract form }\end{array}$} \\
\hline & $\begin{array}{c}\text { Sampel/ } \\
\text { Sample }\end{array}$ & $\begin{array}{c}\text { Ekstrak/ } \\
\text { Extract }\end{array}$ & & \\
\hline Gelidium corneum & 30 & $0.21 \pm 0.003$ & $0.69 \pm 0.010$ & Ekstrak kental/Thick extract \\
\hline Palisada perforate & 30 & $0.91 \pm 0.003$ & $3.03 \pm 0.010$ & Ekstrak kental/Thick extract \\
\hline Sargassum aquifolium & 30 & $0.73 \pm 0.001$ & $2.44 \pm 0.003$ & Pasta/Paste \\
\hline Turbinaria ornate & 30 & $0.74 \pm 0.002$ & $2.48 \pm 0.007$ & Pasta/Paste \\
\hline Ulva lactuca & 30 & $0.35 \pm 0.002$ & $1.18 \pm 0.008$ & Serbuk kering/Dry powder \\
\hline Codium tomentosum & 30 & $1.58 \pm 0.002$ & $5.28 \pm 0.008$ & Ekstrak kental/Thick extract \\
\hline
\end{tabular}


Tabel 2. Kandungan klorofil a, b, dan karotenoid total ( $\mu \mathrm{g} / \mathrm{g}$ berat basah) dari beberapa jenis makroalga Table 2. The chlorophyll $a, b$ and total carotenoid content ( $\mu \mathrm{g} / \mathrm{g}$ fresh weight) of several macroalgal species

\begin{tabular}{lccc}
\hline \multicolumn{1}{c}{ Jenis/Species } & $\begin{array}{c}\text { Klorofil a/ } \\
\text { Chlorophyll a }\end{array}$ & $\begin{array}{c}\text { Klorofil b/ } \\
\text { Chlorophyll b }\end{array}$ & $\begin{array}{c}\text { Total karotenoid/ } \\
\text { Total carotenoid }\end{array}$ \\
\hline Codium tomentosum & $6.73 \pm 0.17^{\mathrm{e}}$ & $9.62 \pm 0.24^{\mathrm{b}}$ & $0.21 \pm 0.04^{\mathrm{b}}$ \\
Ulva lactuca & $7.45 \pm 0.09^{\mathrm{f}}$ & $6.97 \pm 0.10^{\mathrm{a}}$ & $0.10 \pm 0.01^{\mathrm{a}}$ \\
Gelidium corneum & $3.74 \pm 0.19^{\mathrm{c}}$ & - & $0.93 \pm 0.04^{\mathrm{d}}$ \\
Palisada perforate & $1.91 \pm 0.04^{\mathrm{a}}$ & - & $0.67 \pm 0.01^{\mathrm{c}}$ \\
Turbinaria ornata & $4.64 \pm 0.02^{\mathrm{d}}$ & - & $2.25 \pm 0.01^{\mathrm{f}}$ \\
Sargassum aquifolium & $2.74 \pm 0.02^{\mathrm{b}}$ & - & $1.08 \pm 0.01^{\mathrm{e}}$ \\
\hline
\end{tabular}

Keterangan/Note: Simbol huruf yang sama dalam satu kolom menunjukkan tidak adanya perbedaan yang signifikan pada taraf uji statistik 0,05/The same letter in the same column showed that there is no significant difference under the statistical level of 0,05

kemampuan ekstraksi yang rendah terhadap kandungan klorofil. Metanol lebih cocok digunakan untuk ekstraksi pigmen terkait dengan kemungkinan terjadinya epimerisasi klorofil a dalam larutan metanol selama proses ekstraksinya (Dere et al., 1998; Nakamura \& Watanabe, 2001). Hal inilah yang menyebabkan kandungan klorofil a $U$. lactuca pada penelitian ini lebih tinggi karena penggunaan metanol sebagai pelarut.

Klorofil b hanya terdeteksi pada dua jenis makroalga hijau pada penelitian ini. Kandungan klorofil b sampel makroalga hijau menunjukkan bahwa $C$. tomentosum memiliki kadar yang lebih tinggi dibandingkan $U$. lactuca dan secara statistik berbeda nyata $(p<0,05)$. Kandungan klorofil total $(a+b) C$. tomentosum lebih tinggi dibandingkan U. lactuca. Hal ini sesuai dengan morfologi talus $C$. tomentosum yang tampak berwarna hijau lebih gelap dibandingkan talus U. lactuca (Gambar 1).

Klorofil a terdapat pada semua jenis makroalga, dan berperan pada proses penangkapan cahaya untuk

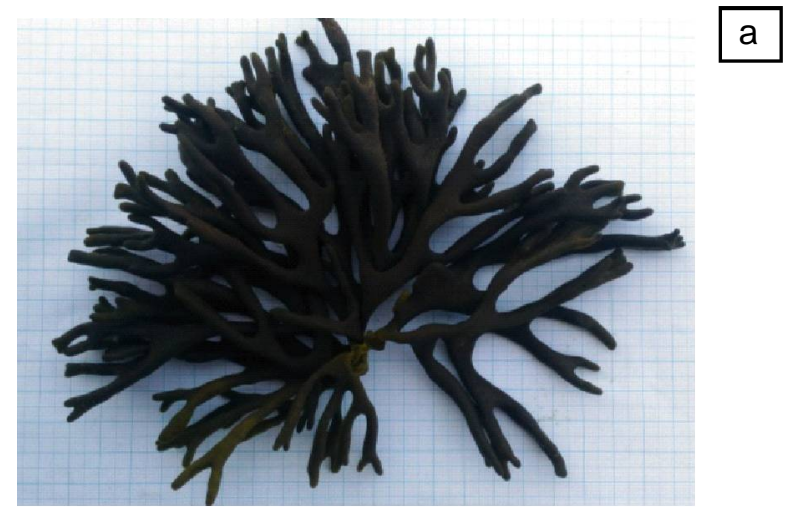

fotosintesis. Beberapa turunan klorofil dikenal sebagai derivat klorofil. Beberapa macam derivat klorofil bersifat spesifik terhadap kelompok alga tertentu. Karena sifatnya yang spesifik, derivat klorofil dapat menjadi penanda golongan kelas makroalga. Klorofil b hanya terdapat pada makroalga hijau, klorofil c pada makroalga coklat, sedangkan klorofil d pada makroalga merah. Pada makroalga, pigmen klorofil merupakan salah satu komponen utama untuk produk-produk nutrasetikal (Stengel, Connan, \& Popper, 2011).

Karotenoid total dari keenam jenis makroalga yang diuji menunjukkan kandungan tertinggi pada $T$. ornata $(2,25 \pm 0,01)$, diikuti oleh $S$. aquifolium $(1,08 \pm 0,01)$. Kedua makroalga tersebut merupakan makroalga coklat yang memang dikenal memiliki pigmen dominan karotenoid. Dominansi karotenoid pada makroalga coklat tampak pada penampakan morfologi talusnya yang berwarna coklat kemerahan sebagai penanda keberadaan pigmen karotenoid.

Pangestuti dan Kim (2011) menyebutkan bahwa alga coklat memiliki karotenoid spesifik fukosantin. Pigmen fukosantin memberi warna coklat pada talus

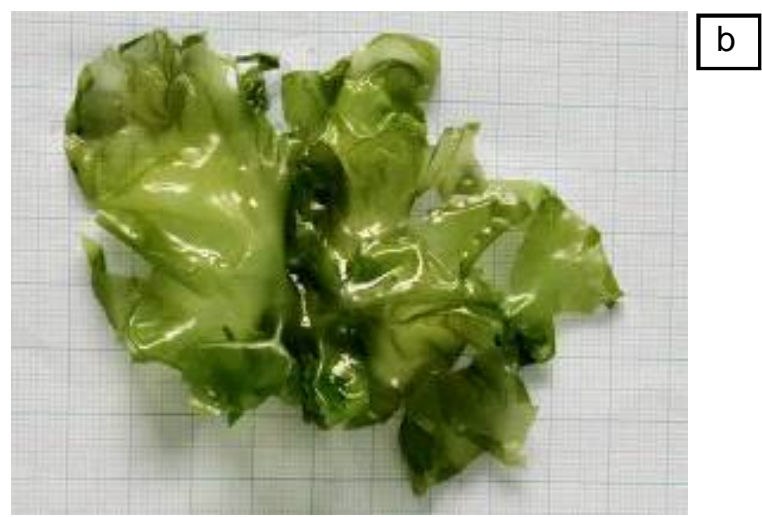

Gambar 1. C. tomentosum (a) dengan warna hijau lebih gelap dibandingkan U. lactuca (b)

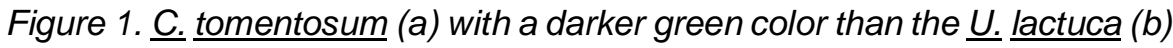


kelompok makroalga coklat. Terasaki et al. (2009) menambahkan bahwa klorofil dan komposisi fukosantin dapat bervariasi di antara jenis dan strain makroalga coklat.

\section{Potensi Antioksidan Makroalga}

Berdasarkan hasil pengukuran potensi antioksidan pada penelitian ini, keenam jenis makroalga berpotensi sebagai antioksidan yang ditunjukkan dengan adanya nilai persentase penghambatan radikal DPPH (Tabel 3). Potensi antioksidan makroalga laut dalam penelitian ini dianalisis dengan mengukur kemampuan ekstrak etanol makroalga dalam menangkap radikal DPPH. Penelitian ini menerapkan satu konsentrasi ekstrak makroalga. Locatelli et al. (2009) menyebutkan pada studinya bahwa nilai $I C_{50}$ yang diperoleh dari aplikasi beberapa seri konsentrasi memang perlu, tapi pada beberapa kasus tertentu, nilai $\mathrm{IC}_{50}$ tersebut tidak dapat menggambarkan kekuatan penangkapan radikal yang sama antara dua jenis sampel berbeda.

Dua jenis sampel berbeda jenis dengan nilai $I_{50}$ yang hampir sama, atau secara statistik tidak menunjukkan perbedaan yang signifikan, tidak selalu menggambarkan kekuatan penangkapan radikal yang sama. Hal ini ditunjukkan pada grafik persentase penghambatan antara kedua jenis sampel berbeda dengan nilai $I C_{50}$ yang hampir sama, dapat memiliki kemiringan grafik yang sangat berbeda. Kemiringan grafik (slope) ini sangat terkait dengan kecepatan penangkapan radikal bebas. Sehingga, dua sampel yang berbeda jenis dengan nilai $I C_{50}$ yang hampir sama belum tentu memiliki kecepatan reaksi yang sama dalam menangkap radikal bebas.

Pada penelitian ini penangkapan radikal $\mathrm{DPPH}$ oleh

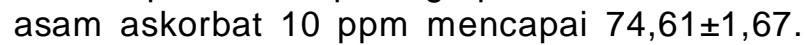

Persentase penangkapan radikal DPPH oleh ekstrak makroalga terbaik diperoleh dari jenis $T$. ornata dengan nilai 79,11 $\pm 0,41$. Meskipun nilai persentase penangkapannya hampir sama, tetapi konsentrasi yang digunakan jauh berbeda. Nilai tersebut menunjukkan bahwa kemampuan penangkapan radikal bebas oleh ekstrak makroalga tidak lebih baik dibandingkan asam askorbat. Perbedaan ini dapat terjadi karena asam askorbat merupakan senyawa tunggal, sementara ekstrak makroalga merupakan senyawa kompleks yang terdiri atas banyak senyawa yang dapat saling mempengaruhi dalam merespon radikal bebas. Nilai persentase tertinggi kedua berasal dari ekstrak S. aquifolium. Kedua jenis makroalga tersebut termasuk kelompok makroalga coklat.

Studi potensi antioksidan pada beberapa jenis makroalga menunjukkan tingginya potensi antioksidan dari makroalga coklat. Makroalga jenis Sargassum crassifolium dari perairan Pulau Sumba, serta Turbinaria decurrens yang berasal dari perairan Sulawesi Utara merupakan contoh jenis makroalga coklat yang memiliki potensi antioksidan yang lebih baik dibandingkan jenis makroalga merah atau hijau (Sanger, Kaseger, Rarung, \& Damongilala, 2018; Supriyono, 2007). Ekstrak makroalga coklat $T$. decurrens dari Pantai Krakal Yogyakarta diketahui mengandung senyawa fenol yang tinggi dan berperan pada aktivitas antioksidannya (Islami et al., 2014). Makroalga coklat Sargassum plagyophyllum dari Pantai Sepanjang, Gunungkidul, Yogyakarta juga memiliki potensi antioksidan dengan senyawa pendukung dari golongan flavonoid, triterpenoid, saponin, alkaloid, dan fenolik (Edison, Diharmi, Ariani, \& IIza, 2020).

Persentase penghambatan radikal DPPH yang dihasilkan oleh ekstrak etanol $T$. ornata pada penelitian ini sedikit lebih rendah dibandingkan yang

Tabel 3. Persentase penangkapan radikal DPPH dari asam askorbat dan ekstrak makroalga

Table 3. The radical DPPH scavenging activities of ascorbic acid and macroalgal extracts

\begin{tabular}{lcc}
\hline \multicolumn{1}{c}{ Sampel/Sample } & $\begin{array}{c}\text { Konsentrasi// } \\
\text { Concentration } \\
\text { (ppm) }\end{array}$ & $\begin{array}{c}\text { Persentase penangkapan DPPH/ } \\
\text { DPPH scavenging activity (\%) }\end{array}$ \\
\hline Asam askorbat/ascorbic acid & 10 & $74.61 \pm 1.67$ \\
Codium tomentosum & 500 & $23.31 \pm 4.11^{\mathrm{b}}$ \\
Ulva lactuca & 500 & $14.75 \pm 2.95^{\mathrm{a}}$ \\
Gelidium corneum & 500 & $20.12 \pm 1.68^{\mathrm{b}}$ \\
Palisada perforate & 500 & $19.10 \pm 3.67^{\mathrm{ab}}$ \\
Turbinaria ornata & 500 & $79.11 \pm 0.41^{\mathrm{d}}$ \\
Sargassum aquifolium & 500 & $54.02 \pm 0.69^{\mathrm{c}}$ \\
\hline
\end{tabular}

Keterangan/Note: Simbol huruf yang sama dalam satu kolom menunjukkan tidak adanya perbedaan yang signifikan pada taraf uji statistik 0,05/The same letter in the same column showed that there is no significant difference under the statistical level of 0,05 
dihasilkan oleh ekstrak $T$. ornata pada studi lainnya. Ananthi, Gayahtri, Chandronitha, Lakshmisundaram, dan Vasanthi (2011) melaporkan bahwa ekstrak air T. ornata yang diperoleh dengan pemanasan menunjukkan kemampuan menghambat radikal DPPH hingga $93,51 \pm 0,60 \%$ pada konsentrasi 500 ppm. Vijayabaskar dan Shiyamala (2012) juga melaporkan nilai peredaman radikal DPPH dari ekstrak metanol $T$. ornata mencapai $84,27 \pm 2,17 \%$ pada konsentrasi yang sama. Perbedaan ini erat kaitannya dengan jenis pelarut yang digunakan untuk ekstraksi. Pelarut yang lebih polar dari etanol tampaknya lebih sesuai untuk menarik senyawasenyawa antioksidan yang terkandung pada ekstrak T. ornata.

Perbedaan lokasi tumbuh kemungkinan berpengaruh terhadap kadar senyawa antioksidan yang dihasilkan $T$. ornata. Senyawa antioksidan banyak yang termasuk dalam golongan metabolit sekunder yang produksinya sangat dipengaruhi oleh kondisi lingkungan yang menjadi habitatnya. Bedoux dan Bourgougnon (2016) menyebutkan bahwa makroalga memproduksi berbagai jenis metabolit sekunder yang bersifat bioaktif luas, termasuk sifat antioksidatif. Produksi metabolit sekunder tersebut merupakan respon terhadap lingkungan tempat tumbuhnya. Senyawa antioksidatif pada makroalga dihasilkan sebagai respon terhadap terbentuknya Reactive Oxygen Species (ROS) akibat stres lingkungan yang dihadapi.

\section{Korelasi Kandungan Pigmen dengan Potensi Antioksidan Makroalga}

Analisis korelasi Pearson dilakukan untuk mengetahui korelasi antara potensi antioksidan ekstrak makroalga dengan kandungan beberapa pigmen yang diukur pada penelitian ini. Korelasi hanya diujikan pada pigmen klorofil a dan total karotenoid, karena ketiadaan klorofil b pada makroalga merah dan coklat. Hasil analisis korelasi Pearson menunjukkan bahwa hanya kandungan total karotenoid yang berkorelasi positif dengan potensi antioksidan ekstrak makroalga $\left(R^{2}=0,806 ; p<0,05\right)$, sementara kandungan klorofil a tidak berkorelasi dengan potensi antioksidan makroalga (Gambar 2).

Berdasarkan informasi dari beberapa studi, karotenoid telah diketahui memiliki keterkaitan yang kuat dengan aktivitas antioksidan makroalga (Foo et al., 2017; Hu, Lin, Lu, Chou, \& Yang, 2008; Rao, Sarada, Baskaran, \& Ravishankar, 2009). Pangestuti dan Kim (2011) menyebutkan bahwa pigmen alga tidak hanya berfungsi sebagai pewarna, tetapi dapat berkontribusi terhadap potensi antioksidan. Beberapa pigmen terbukti berperan dalam aktivitas antioksidan, seperti karotenoid, klorofil a dan derivatnya.

Pada penelitian ini, hasil analisis statistik menunjukkan adanya korelasi positif antara aktivitas penghambatan radikal DPPH dengan kandungan total karotenoid. Ekstrak T. ornata yang menunjukkan aktivitas penghambatan radikal DPPH tertinggi pada penelitian ini diduga mengandung karotenoid spesifik alga coklat yaitu fukosantin sebagaimana hasil dari beberapa studi (Sachindra et al., 2007; Yan, Chuda, Suzuki, \& Nagata, 1999). Keberadaan ikatan rangkap allenic pada molekul fukosantin diduga berkaitan erat dengan tingginya kemampuan dalam menangkap radikal bebas (Sachindra et al., 2007).

Pada penelitian ini, kandungan klorofil a tidak menunjukkan adanya korelasi dengan potensi antioksidan ekstrak makroalga, berbeda dengan hasil studi sebelumnya (Cahyana, Shuto, \& Kinoshita, 1993). Tidak adanya korelasi yang terbentuk antara aktivitas penghambatan radikal DPPH dengan kandungan klorofil a pada penelitian ini kemungkinan
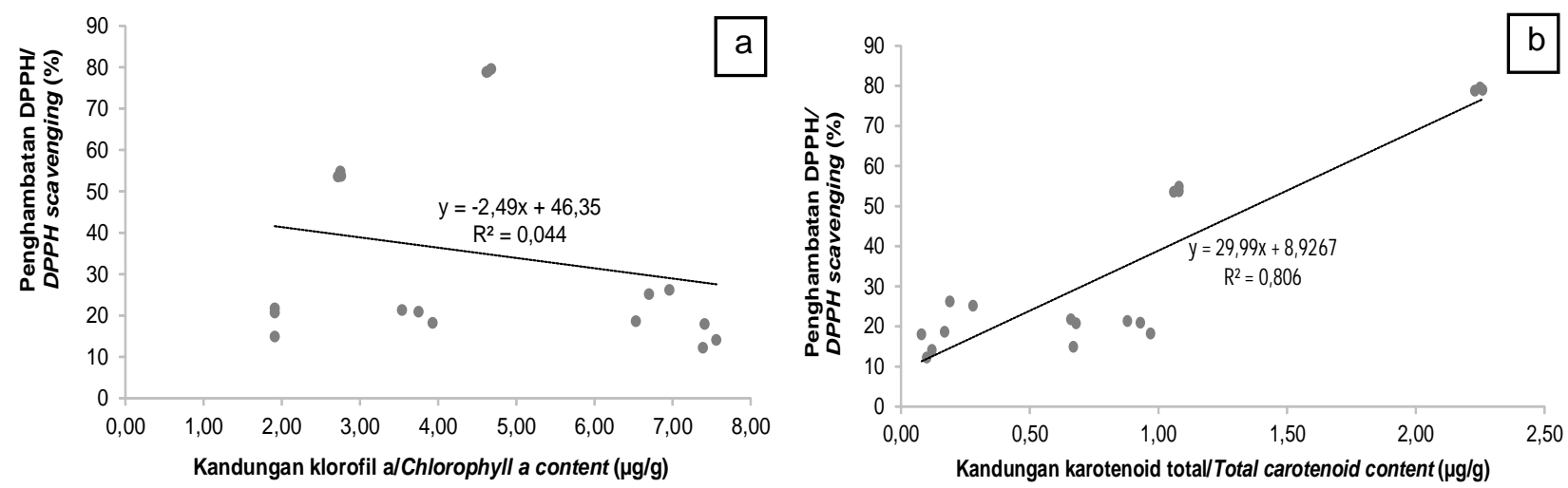

Gambar 2. Hubungan aktivitas penghambatan DPPH dengan (a) kandungan klorofil a, dan (b) kandungan total karotenoid

Figure 2. Relation between DPPH scavenging activity with (a) chlorophyll a content and (b) total carotenoid content 
terjadi karena klorofil a yang terkandung dalam 500 ppm ekstrak belum mencukupi batas minimal yang dibutuhkan untuk memicu fungsi penghambatan radikal bebas. Lanfer-Marquez, Barros, \& Sinnecker (2005) menyebutkan bahwa klorofil a dapat menunjukkan aktivitas antioksidan terhadap radikal DPPH pada konsentrasi tinggi yaitu sekitar $1 \mathrm{mM}$.

Selain pigmen alami makroalga yang menjadi pembahasan utama pada penelitian ini, berbagai jenis makroalga telah terbukti menghasilkan senyawa antioksidan. Senyawa-senyawa golongan fenolik seperti flavonoid dan florotanin banyak dihasilkan makroalga sebagai respon terhadap adanya tekanan oksidatif yang terjadi. Senyawa-senyawa tersebut dapat saling berkontribusi pada aktivitas antioksidan makroalga (Potin, 2015). Penelaahan lebih mendalam mengenai senyawa-senyawa antioksidan makroalga akan semakin melengkapi informasi potensi antioksidan makroalga Indonesia.

\section{KESIMPULAN}

Hasil pengukuran pigmen pada penelitian ini menunjukkan bahwa kadar tertinggi klorofil a terdapat pada makroalga jenis $U$. lactuca, klorofil b pada $C$. tomentosum, dan total karotenoid pada $T$. ornata. Semua jenis makroalga yang diuji pada penelitian ini menunjukkan potensi antioksidan, dengan potensi tertinggi pada jenis $T$. ornata. Analisis korelasi menunjukkan bahwa aktivitas penghambatan radikal DPPH berkorelasi positif dengan kandungan total karotenoid makroalga, tetapi tidak berkorelasi dengan kandungan klorofil a nya.

\section{UCAPAN TERIMAKASIH}

Ucapan terimakasih disampaikan kepada Pusat Pendidikan Kelautan dan Perikanan, Kementerian Kelautan dan Perikanan yang telah memberikan dukungan dana pada penelitian ini sebagai bagian dari program beasiswa pendidikan master pada Fakultas Biologi Universitas Gadjah Mada. Kami juga berterima kasih kepada Bapak Teguh Hermawan yang telah memberikan dukungan teknis selama pelaksanaan penelitian ini.

\section{DAFTAR PUSTAKA}

Agoes, G. (2009). Teknologi bahan alam (Serial Farmasi Industri-2). Bandung, Penerbit ITB.

Ajisaka, T. \& Kilar, J. A. (1990). Turbinaria sp. (Phaeophyceae, Sargassaceae) from Iwayana Bay, Palau Islands (Western Caroline Island). South Pacific Study, 10(2), 235-240.

Ananthi, S., Gayathri, V., Chandronitha, C., Lakshmisundaram, R., \& Vasanthi, H.R. (2011). Free radical scavenging and anti-inflammatory potential of a marine brown alga Turbinaria ornata (Turner) J. Agardh. Indian Journal of Geo-Marine Sciences, 40(5), 664-670.

Bedoux, G. \& Bourgougnon, N. (2016). Bioactivity of secondary metabolites from macroalgae. In Sahoo, D \& Seckbach, J. (Ed). The Algae World (pp : 391401). London, England: Springer.

Budhiyanti, S. A., Raharjo, S., Marseno, D. W., \& Lelana, I. Y. B. (2012). Antioxidant activity of brown algae Sargassum species extract from the coastline of Java Island. American Journal of Agricultural and Biological Sciences, 7(3), 337-346.

Cahyana, A. H., Shuto, Y., \& Kinoshita, Y. (1993). Antioxidative activity of Porphyrin Derivetives. Bioscience, Biotechnology, and Biochemistry, 57(4), 680-681. doi:10.1271/bbb.57.680

Cassano, V., Diaz-Larrea, J., Senties, A., Oliviera, M.C., Gil-Rodriguez, M.C., \& Fujii, M.T. (2009). Evidence for conspesificity of Palisada pappilosa with P. perforata (Ceramiales, Rodophyta) from the western and eastern Atlantic Ocean on the basis of morphological and molecular analyses. Phycologia, 48(2), 86-100. doi: 10.2216/0031-8884-48.2.86

Da Costa, J. F., Merdekawati, W., \& Out, F. R. (2018). Analisis proksimat, aktivitas antioksidan, dan komposisi pigmen Ulva lactuca L. dari Perairan Pantai Kukup. Jurnal Teknologi Pangan dan Gizi, 17 (1), 1-17. doi:10.33508/jtpg.v17i1.1697

Dere, S., Gunes, T., \& Sivaci, R. (1998). Spectrophotometric determination of chlorophyll-A, B and total carotenoid contents of some algae species using different Solvents. Turkish Journal of Botany, 13-17.

Edison, Diharmi, A., Ariani, N.M., \& Ilza, M. (2020). Komponen bioaktif dan aktivitas antioksidan ekstrak kasar Sargassum plagyophyllum. Jurnal Pengolahan Hasil Perikanan Indonesia, 23(1), 58-66.

Febrianto, W., Djunaedi, A., Suryono, Santosa, G.W., \& Sunaryo. (2019). Potensi antioksidan rumput laut Gracilaria verrucosa dari Pantai Gunungkidul, Yogyakarta. Jurnal Kelautan Tropis, 22(1), 81-86. doi:10.14710/jkt.v22i1.4669

Foo, S. C., Yusoff, F. M., Ismail, M., Basri, M., Yau, S. K., Khong, N. M., ... \& Ebrahimi, M. (2017). Antioxidant capacities of fucoxanthin-producing algae as influenced by their carotenoid and phenolic contents. Journal of Biotechnology, 241, 175-183. doi: 10.1016/ j.jbiotec.2016.11.026

Guiry, M. D., \& Guiry, G. M. (2019). Algaebase.World-wide electronic publication, National University of Ireland, Galway. Diakses dari: http://algaebase.org.

Hu, C. C., Lin, J. T., Lu, F. J., Chou, F. P., \& Yang, D. J. (2008). Determination of carotenoids in Dunaliella salina cultivated in Taiwan and antioxidant capacity of the algal carotenoid extract. Food Chemistry, 109(2), 439-446. doi:10.1016/j.foodchem.2007.12.043

Islami, F., Ridlo, A., \& Pramesti, R. (2014). Aktivitas antioksidan ekstrak Turbinaria decurrens Bory De SaintVincent dari Pantai Krakal, Gunungkidul, Yogyakarta. Journal of Marine Research, 3(4), 605-616. 
Jan-Malta, E., Draisma, S. G. A., \& Kamermans, P. (1999). Free-floating Ulva in the southwest Netherlands: species or morphotypes? A morphological, molecular and ecological comparison. European Journal of Phycology, 34(5), 443-454. doi : 10.1080/ 09541449910001718801

Kantachumpoo, A., Uwai, S., Noiraksar, T., \& Komatsu, T. (2015). Systematic of marine brown alga Sargassum from Thailand: a preliminary study based on morphological data and nuclear ribosomal Internal transcribed spacer 2 (ITS2) sequences. Ocean Science Journal, 50(2), 251-262. doi:10.1007/ s12601-015-0022-4

Kosanic, M., Rankovic, B., \& Stanojkovic, T. (2019). Brown macroalgae from Adriatic Sea as a promising source of bioactive nutrients. Journal of Food Measurement and Characterization, 13, 330-338. doi:10.1007/ s11694-018-9948-4

Kumar, P., Ramakritinan, C. M., \& Kumaraguru, A. K. (2010). Solvent extraction and spectrophotometric determination of pigments of some algal species from the shore of Puthumadam, Southeast Coast of India. International Journal of Oceans and Oceanography, 4(1), 29-34.

Kurniasih, S. D., Pramesti, R., \& Ridlo, A. (2014). Penentuan aktivitas antioksidan ekstrak rumput laut Ulva sp. dari Pantai Krakal, Yogyakarta. Journal of Marine Research, 3(4), 617-626. doi:10.14710/ jmr.v3i4.11423

Lanfer-Marquez, U. M., Barros, R. M. C., \& Sinnecker, P. (2005). Antioxidant activity of chlorophylls and their derivatives. Food Research International, 38(8-9), 885-891. doi: 10.1016/j.foodres.2005.02.012

Lee, H. W., Kang, J. C., \& Kim, M. S. (2019). Taxonomy of Ulva causing blooms from Jeju Island, Korea with new species, U. pseudo-ohnoi sp.nov. (Ulvales, Chlorophyta). Algae, 34(4), 253-266. doi: 10.4490/ algae.2019.34.12.9.

Lee, I. K., Hwang, M. S., \& Oh, Y. S. (1992). Notes on marine algae from Korea (IV). The Korean Journal of Phycology, 7(2), 257-268.

Lee, Y. P. (1988). Taxonomic studies on the Gelidiaceae (Rhodophyta) in Cheju Island. Korean Journal of Plant Taxonomy, 18(2), 95-113.

Lichtenthaler, H. K., \& Buschmann, C. (2001). Chlorophylls and carotenoids : measurement and characterization by UV-Vis Spectroscopy. Current Protocols in Food Analytical Chemistry, 1(1), F4.3.1F4.3.8. doi: 10.1002/0471142913.faf0403s01

Locatelli, M., Gindro, R., Travaglia, F., Coisson, J. D. Rinaldi, M., \& Arlorio. M. (2009). Study of the DPPHscavenging activity : development of a free software for the correct interpretation of data. Food Chemistry, 114, 889-897. doi : 10.1016/j.foodchem.2008.10.035

Lutfiyanti, R., Ma'ruf, W. F., \& Dewi. E. N. (2012). Aktivitas antijamur senyawa bioaktif ekstrak Gelidium latifolium terhadap Candida albicans. Jurnal Pengolahan dan Bioteknologi Hasil Perikanan, 1(1), 26-33.

Martin-Lescanne, J., Rousseau, De Reviers, B., Payri, C., Couloux, A., Cruaud, C., \& Le Gall, L. (2010).
Phylogenetic analyses of the Laurencia complex (Rhodomelaceae, Ceremiales) support recognition of five genera: Chondrophycus, Laurencia, Osmundea, Palisada, and Yuzurua stat.nov. European Journal of Phycology, 45(1), 51-61. doi: 10.1080/09670260903314292

Merdekawati, W. \& Susanto, A. B. (2009). Kandungan dan komposisi pigmen rumput laut serta potensinya untuk kesehatan. Squalen Bulletin of Marine and Fisheries Postharvest and Biotechnology, 4(2), 4147.

Munir, N., Sharif, N., Naz, S., \& Manzoor F. (2013). Algae : A potential antioxidant source. Sky Journal of Microbiology Research, 1(3), 22-31.

Nakamura, A. \& Watanabe, T. (2001). Separation and determination of minor photosynthetic pigments by reversed-phase HPLC with minimal alteration of chlorophylls. Analytical Sciences, 17, 503-508. doi:10.2116/analsci.17.503

Navya, P. \& Khora, S. S. (2017). Ultrasonic-enhanched and hot water extraction of antioxidant sulfated polysaccharides from Codium tomentosum Stackhouse, 1797. Biomedical Research, 28(20), 8682-8689.

Nopiyanti, V., \& Harjanti, R. (2016). Analisis stabilitas senyawa aktif antioksidan kelopak bunga Rosella (Hibiscus sabdariffa L.) pada penggunaannya sebagai bahan tambahan pangan alami. Jurnal Farmasi Indonesia, 13(2), 101-110.

Oliviera-Carvalho, M. F., Pereira, S. M. B., \& Pedroche, F.F. (2010). Taxonomy and distribution of the green algal genus Codium (Bryopsidales, Chlorophyta) in Brazil. Nova Hedwigia, 91(1-2), 87-109. doi: 10.1127/ 0029-5035/2010/0091-0087

Pangestuti, R., \& Kim, S.W. (2011). Biological activities and health benefit effects of natural pigments derived from marine algae. Journal of Functional Foods, 3, 255-266. doi : 10.1016/j.jff.2011.07.001

Perrone, C., Felicini, G. P., \& Bottalico, A. (2006). The prostrate system of the Gelidiales: diagnostic and taxonomic importance. Botanica Marina, 49, 23-33. doi: 10.1515/BOT.2006.003

Potin, P. (2015).Oxidative burst and related responses in biotic interaction of algae. In Amsler, C.D. Algal Chemical Ecology (pp: 245-272). Berlin : Springer.

Pramesti, R., Ridlo, A., Setyati, W.A., Zainuddin, M., \& Akbar, M.R. (2017). Aktivitas antioksidan rumput laut Acanthophora muscoides (L.) Bory dari Pantai Krakal Gunungkidul, Yogyakarta. Jurnal Disprotek, 8(1), 4656. doi:10.34001/jdpt.v8i1.485

Rao, R., Sarada, A. R., Baskaran, V., \& Ravishankar, G. A. (2009). Identification of carotenoids from green alga Haematococcus pluvialis by HPLC and LC-MS (APCI) and their antioxidant properties. Journal of Microbiology and Biotechnology, 19(11), 1333-1341. doi: 10.4014/jmb.0905.03007

Rezayian, M., Niknam, V., \& Ebahimsadeh. (2019). Oxidative damage and antioxidative system in algae. Toxicology Reports, 6, 1309-1313. doi: 10.1016/ j.toxrep.2019.10.001 
Sachindra, N., Sato, E., Maeda, H., Hosokawa, M., Niwano, Y., \& Kohno, M. (2007). Radical scavenging and singlet oxygen quenching activity of marine carotenoid fucoxanthin and its metabolites. Journal of Agricultural and Food Chemistry 55, 8516-8522. doi: 10.1021/jf071848a

Sanger, G., Kaseger, B. E., Rarung, L. K., \& Damongilala, L. (2018). Potensi beberapa jenis rumput laut sebagai bahan pangan fungsional, sumber pigmen dan antioksidan alami. Jurnal Pengolahan Hasil Perikanan Indonesia, 21(2), 208-217. doi:10.17844/ jphpi.v21i2.22841

Santos-Sánchez, N. F., Salas-Coronado, R., VillanuevaCañongo, C., \& Hernández-Carlos, B. (2019). Antioxidant compounds and their antioxidant mechanism (pp. 1-28). London, UK: IntechOpen. doi:10.5772/intechopen.85270

Sedjati, S., Suryono, Santosa, A., Supriyantini, E., \& Ridlo, A. (2017). Aktivitas antioksidan dan kandungan senyawa fenolik makroalga coklat Sargassum sp. Jurnal Kelautan Tropis, 20 (2), 117-123. doi:10.14710/ jkt.v20i2.1737

Seedevi, P., Sudharsan, S., Kumar, S. V., Srinivasan, A Vairamani, S., \& Shanmugam. A. (2013). Isolation and characterization of sulphated polysaccharides from Codium tomentosum (J. Stackhouse, 1797) collected from southeast if India. Advances in Applied Science Research 4(5), 72-77.

Silva, P. C. (1955). The dichotomous species of Codium in Britain. Journal of the Marine Biological Association of United Kingdom, 34, 565-577.

Steffensen, D. A. (1976). Morphological variation of Ulva in the Avon-Heathcote Estuary, Christchurch. New Zealand Journal of Marine and Freshwater Research, 10(2), 329-341. doi: 10.1080/00288330.1976.9515616

Stengel, D. B., Connan, S., \& Popper, Z. A. (2011). Algal chemodiversity and bioactivity : sources of natural variability and implication for commercial application. Biotechnology Advances, 29(5), 483-501. doi: 10.1016/j.biotechadv.2011.05.016

Stewart, H. L. (2006). Morphological variation and phenotypic plasticity of buoyancy in the macroalgae Turbinaria ornata across a barrier reef. Marine Biology, 149, 721-730. doi: 10.1007/s00227-005-0186-z.

Supriyono, A. (2007). Aktivitas antioksidan beberapa spesies rumput laut dari Pulau Sumba. Jurnal Sains dan Teknologi Indonesia, 9(1), 34-38.

Terasaki, M., Hirose, A., Narayan, B., Baba, Y., Kawagoe, C., Yasui, H., ... \& Miyashita, K. (2009). Evaluation of recoverable functional lipid components of several brown seaweeds (Phaeophyta) from Japan with special reference to fucoxanthin and fucosterol contents 1 . Journal of phycology, 45(4), 974-980. doi : 10.1111/j.1529-8817.2009.00706

Trowbridge, C. D. (2001). Coexistence of introduced and native congeneric algae: Codium fragile and $C$. tomentosum on Irish rocky intertidal shores. Journal of the Marine Biological Association of United Kingdom, 81(3841), 1-7. doi: 10.1017/S0025315401004854.

Vijayabaskar, P. \& Shiyamala, V. (2012). Antioxidant properties of seaweed polyphenol from Turbinaria ornata (Turner) J. Agardh, 1848. Asian Pacific Journal of Tropical Biomedicine, 2(1), S90-S98. doi : 10.1016/ S2221-1691(12)60136-1.

Yan, X., Chuda, Y., Suzuki, M., \& Nagata, T. (1999). Fucoxanthin as the major antioxidant in Hijikia fusiformis, a common edible seaweed. Journal Bioscience, Biotechnology, and Biochemistry, 63(3), 605-607. doi: 10.1271/bbb.63.605.

Yip, Z. T., Quek, R. Z., Low, J. K., Wilson, B., Bauman, A. G., Chou, L. M., ... \& Huang, D. (2018). Diversity and phylogeny of Sargassum (Fucales, Phaeophyceae) in Singapore. Phytotaxa, 369(3), 200-210. doi:10.11646/phylotaxa.369.3.3 